\title{
Reduction of the frequency of herbaceous roots as an effect of soil compaction induced by heavy grazing in rangelands of SW Spain
}

\author{
Manuel Pulido $^{\mathrm{a}, *}$, Susanne Schnabel ${ }^{\mathrm{a}}$, J. Francisco Lavado Contador ${ }^{\mathrm{a}}$, Javier Lozano-Parra ${ }^{\mathrm{a}, \mathrm{b}}$, \\ Álvaro Gómez-Gutiérrez ${ }^{\mathrm{a}}$, Eric C. Brevik ${ }^{\mathrm{c}}$, Artemi Cerdà ${ }^{\mathrm{d}}$ \\ a GeoEnvironmental Research Group, University of Extremadura, Cáceres, Spain \\ b Department of Physical Geography, Pontifical Catholic University of Chile, Santiago, Chile \\ c Department of Natural Sciences, Dickinson State University, Dickinson, ND, USA \\ ' Soil Erosion and Degradation Research Group (SEDER), Departament de Geografia, Universitat de València, Valencia, Spain
}

\section{A R T I C L E I N F O}

\section{Keywords:}

Penetration resistance

Bulk density

Livestock

Dehesas

Animal stocking rates

\begin{abstract}
A B S T R A C T
Rangelands in SW Spain constitute the most extensive ranching system on the Iberian Peninsula. During the last few decades, a significant increase in livestock numbers, along with a progressive substitution of cattle for sheep, have led to land degradation processes such as the reduction of grass cover and increased soil compaction in heavily grazed areas. Nevertheless, a better understanding of how soil compaction affects grass production is still needed. In this study, some of the effects of soil compaction due to heavy grazing are analysed, mainly the reduction of the frequency of herbaceous roots and its relationships with bulk density and soil penetration resistance. The study was carried out in 22 fenced areas grazed under different intensities (animal stocking rates: 0.19-15.76 $\mathrm{AU} \mathrm{ha}^{-1}$ ). Undisturbed soil core and bulk samples were collected at 3 depth intervals in order to determine select soil properties (texture, organic matter content, and bulk density). Additionally, soil penetration resistance was quantified at 890 random points at different depths and soil moisture contents. Frequency of herbaceous roots was estimated for each soil horizon in 47 soil profiles and categorized into 4 classes: none, few, common and many. Results showed negative relationships between bulk density ( $>10 \mathrm{~cm}$ depth) and the content of soil organic matter from 0 to $5 \mathrm{~cm}(r=-0.061, p<0.05)$ and 5-10 m depth $(r=-0.824$, $p<0.005$ ). Furthermore, a tendency for decreasing mean values of soil penetration resistance as the frequency of herbaceous roots increased was also observed. The values observed confirm that soil compaction provoked by an excessive number of animals reduced the quantity of herbaceous roots. The value of $2 \mathrm{MPa}$ traditionally accepted as restrictive for root growth is discussed. Findings presented here could be of interest for policy makers and farm owners to guide decisions about optimum animal stocking rates.
\end{abstract}

\section{Introduction}

Southern Europe is geographically conditioned both by a wide dominance of Mediterranean climate type (Cs, Köppen classification) and by intensive anthropogenic activity since ancient times (King et al., 2014). The climate and historical land pressure have shaped the landscape, converting former Mediterranean oak forests by clear-cutting shrubs, removing selected trees, and cultivating the soils to serve as croplands or rangelands depending on local soil capability (Marañón et al., 2009).

The consequences induced by edaphic constraints such as shallow soils and poor nutrient content are particularly visible in the SW Iberian Peninsula where large areas of land are managed as rangelands (Pulido and Picardo, 2010). Furthermore, a temporal rainfall pattern where summers are regularly dry and hot prevents high pasture yields during some critical periods of the year (Schnabel, 1997). These natural limitations have evolved to a predominance of extensive grazing in which the number of animals has been traditionally well-adapted to pasture productivity (Pardini, 2002).

Nowadays rangelands in the SW Iberian Peninsula cover a land surface of $>6$ million ha (Joffre et al., 1999) where millions of domestic animals (6.5 million sheep, 3.0 million pigs, 1.8 million cows, and 0.5 million goats) are extensively ranched in large privately-owned farms (Plieninger et al., 2004). This system traditionally assumed an average animal stocking rate of about $0.70 \mathrm{AU} \mathrm{ha}^{-1} \mathrm{yr}^{-1}$ (1 cow $=1 \mathrm{AU}, 1 \mathrm{pig}=0.37 \mathrm{AU}, 1$ sheep $/$ goat $=0.12 \mathrm{AU}$ ), but this has been considerably increased since Spain and Portugal joined the European Union in 1986 and began to participate in its Common

\footnotetext{
* Corresponding author.

E-mail addresses: mapulidof@unex.es (M. Pulido), artemio.cerda@uv.es (A. Cerdà).
} 


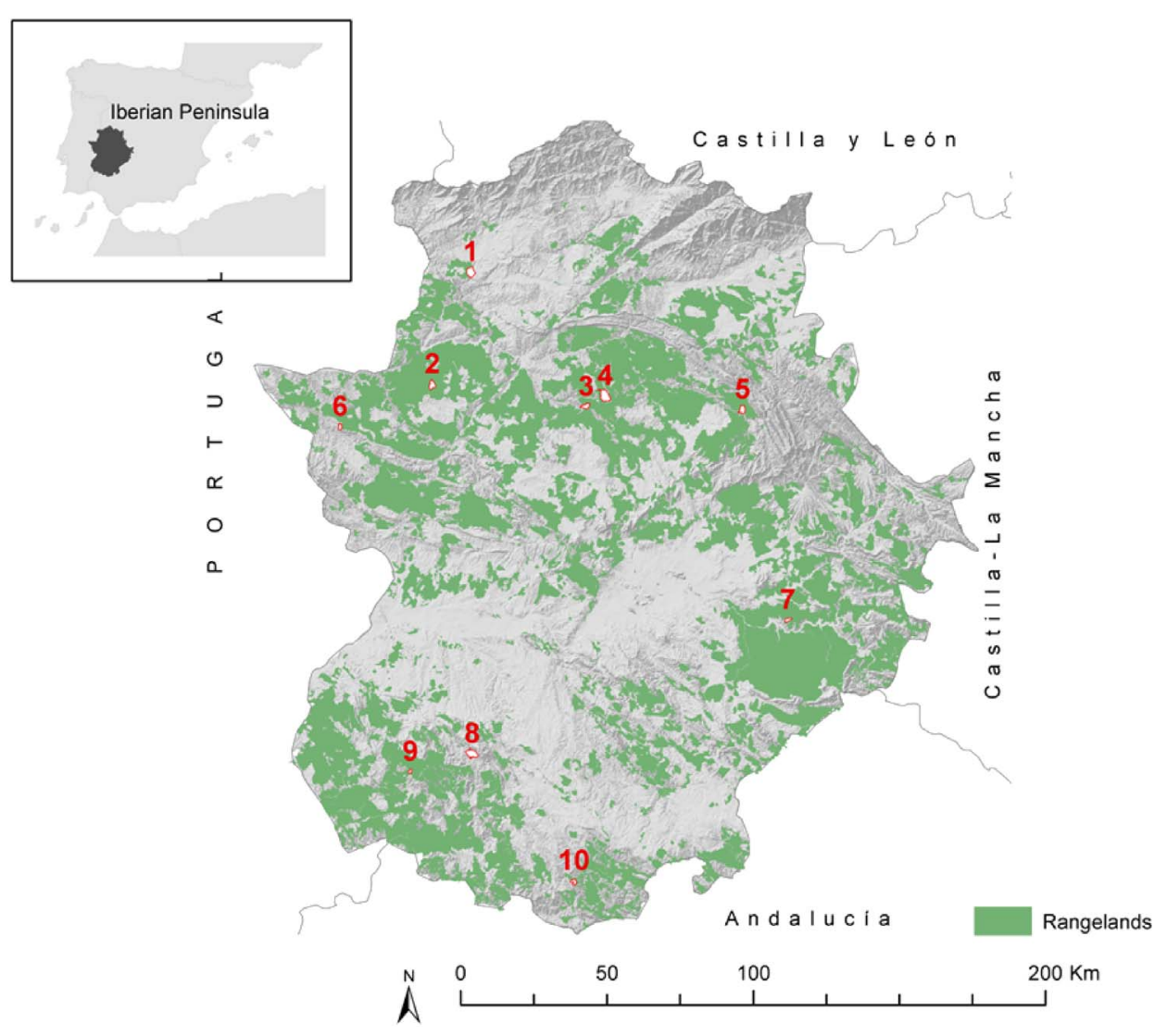

Fig. 1. Location of the study farms in the region of Extremadura (Spain).

Agricultural Policy (CAP) subsidies (Gonzalo Langa, 2011).

The rangelands of the SW Iberian Peninsula are generally formed of isolated trees (holm oak and cork oak) and herbaceous pastures mostly composed of therophytic species and occasionally by patches of shrubs of variable density, extension and composition (Díaz et al., 1997). These pastures, along with the fruit of the holm oak, the acorn, are the main source of natural feed for the animals (Gea-Izquierdo et al., 2006). Good management of these resources could save farmers $>500$ euros per animal unit per year (economic data of 2011), without considering the economic value of the environmental benefits (Pulido Fernández, 2014).

Mismanagement in the form of excessive animal numbers causes the deterioration of soil quality through land degradation processes (Bilotta et al., 2007), eventually leading to reduced pasture productivity (Drewry et al., 2008). Soils under pasture can be compacted as a result of the pressure exerted on the ground by grazing animals, comparable to that of agricultural machinery (Greenwood and McKenzie, 2001). For most soils, compaction changes their structure (Gupta et al., 1989), increases soil strength and penetration resistance, which results in impeded root development and plant growth (Greacen and Sands, 1980).

Many studies under different agroecosystems have proven that continuous grazing leads to increasing soil compaction with increasing animal stocking rates (Willat and Pullar, 1984; Mulholland and Fullen, 1991; Donkor et al., 2002). Nevertheless, soil compaction is influenced by many other factors such as rainfall, slope, soil texture, soil water content, and animal species (Greenwood and McKenzie, 2001). Furthermore, soil compaction can be assessed through different variables such as bulk density and penetration resistance that can be interrelated but their relationships are very complex (Gerrard, 1982; Voorhees, 1983).

An animal can walk several kilometres a day in order to find food (e.g. acorns) or water in summer within the boundaries of a regular Iberian rangeland farm (Lachica and Aguilera, 2000). In addition, these farms are increasingly fragmented into fenced areas where animals are forced to stay in or out for several days (Lavado Contador et al., 2015). The effects of animal treading on soil physical properties and pasture yield comparing different livestock management, soil type, and climate conditions have been reviewed worldwide by Greenwood and McKenzie (2001) and Drewry et al. (2008).

Iberian rangelands soils should be a priori less prone to compaction than most soils because of their low clay contents (sandy-loam texture on average), undulating topography (slope: $2-8 \%$ ), and lower typical animal stocking rates (Pulido Fernández, 2014) as compared to more humid areas. In fact, Pulido et al. (2016) only found significantly higher values of bulk density at the $5-10 \mathrm{~cm}$ depth interval (not at the surface) in farms with animal stocking rates above $1 \mathrm{AU} \mathrm{ha}^{-1} \mathrm{yr}^{-1}$, lower stocking rates did not result in soil compaction.

These findings suggest it is necessity to engage in deeper investigations on the role played by the frequency and distribution of fine roots as evidence of soil compaction effects. The biological activity of herbaceous roots in soils of rangelands in SW Spain is concentrated within the first $10 \mathrm{~cm}$ (Moreno et al., 2005; Pulido-Fernández et al., 2013). Soil compaction therefore reduces grass production (Brevik et al., 2002; Whalley et al., 2008) due to decreased development of roots and plant shoots (Glab, 2013), which consequently reduces the frequency of roots and soil porosity.

The frequency and distribution of herbaceous roots are consequently related to soil penetration resistance and its known root-growth limits. Taylor et al. (1966), for instance, proposed a limiting penetration resistance value of $2.5 \mathrm{MPa}$, above which growth of herbaceous roots seldom occurs or does not occur. Subsequently, other authors have suggested thresholds ranging from 2.0 MPa (Greacen, 1986; Atwell, 1993) or 3.0 MPa (Busscher and Sojka, 1987; Hakansson and Lipiec, 2000) up to the $8 \mathrm{MPa}$ reported by Glinski and Lipiec (1990) in ryegrass fields. These limits can vary depending on type of soils or vegetation species (Bengough, 1991).

Taking into account the abovementioned, a better understanding of how soil compaction caused by heavy grazing affects the frequency and 
distribution of herbaceous roots, and a more accurate value of the rootgrowth restricting penetration resistance in these land systems is still needed. Therefore, the main goal of this research was to analyze soil compaction values (bulk density and penetration resistance) and their relationships with the frequency of herbaceous roots observed at different depths in rangelands under varying grazing intensities.

\section{Material and methods}

\subsection{Study areas}

The study was carried out at ten privately-owned farms distributed throughout the Extremadura region (SW Spain), where rangelands cover $>2$ million ha (Fig. 1). The farms were located at variable altitudes ranging from 299 to $695 \mathrm{~m}$ with sizes varying from 137 to 1024 ha. The dominant landforms are old erosion surfaces formed in Precambrian shales and greywackes (Gómez Amelia, 1985). The landscape is characterized by gently undulating surfaces, dissected by a river network that gives rise to increasingly steep slopes as one approaches the main rivers. The vegetation is heterogeneous in space with areas covered by grasslands, scrublands and woodlands of varying shrub and tree densities. The most common tree species are holm oak (Quercus ilex) and cork oak (Quercus suber). Shrubs are also present in some units, with Retama sphaerocarpa being, by far, the most dominant species. The herbaceous layer is dominated by therophytic pastures rich in gramineous, legumes, composites, plantaginaceae, geraniaceae and other species (González et al., 2007).

A total of 22 fenced areas with different land management were selected as study areas, with sizes varying from 2.8 to 146.2 ha. They were composed of grasslands with a varying degree of tree cover, ranging from treeless to 150 trees $^{-1} \mathrm{a}^{-1}$, and were grazed by different animal species. Climatic conditions varied from semiarid to dry subhumid with mean annual rainfall ranging from 505 to $732 \mathrm{~mm}$ (Ninyerola et al., 2005), a wet season from October to May, and a pronounced hot and dry period during the summer, particularly in July and August. The main soil types were Cambisols and Leptosols. Pastures in the study area were grazed by sheep, pigs, cattle and goats in variable densities and combinations. Animal stocking rates ranged from 0.19 to 15.76 $\mathrm{AU} \mathrm{ha}^{-1}$ (Table 1).

\subsection{Soil sampling}

Soil sampling was conducted in comparable areas (i.e. midslope, same aspect, etc.) (Lozano-García et al., 2016) selected as sampling sites within the 22 study areas (units). Field work consisted mostly of the description and characterization of the soils focusing on soil properties such as bulk density and penetration resistance and on the abundance of herbaceous roots and their vertical distribution. Most of samples (bulk and undisturbed cores) were collected in open spaces randomly selected within representative areas of 22 units (sampling sites).

A total of 47 soil profiles ( $\approx 2$ per study area) were described (FAO, 2006) in order to characterize the soils and to obtain relevant information about the herbaceous roots.

Herbaceous roots were described for each soil horizon and categorized in 4 classes according to their abundance: none, few, common and many. According to FAO (2006), none corresponds to a quantity of roots ( $<2 \mathrm{~mm}$ diameter observed in $2 \mathrm{~cm}^{2}$ surface area) $<20$, few between 20 and 50, common between 50 and 200 and, finally, many corresponds to $>200$ roots observed (Supplementary Material S1).

Approximately 15 bulk samples were randomly collected at each site (totaling 319 bulk samples) from three depth intervals $(0-5 \mathrm{~cm}$, $5-10 \mathrm{~cm}$ and $>10 \mathrm{~cm}$ ) in order to determine soil properties such as grain size distribution (Soil Survey Laboratory Methods Manual, 2004) and soil organic matter (Walkley and Black, 1934). In addition, 597 undisturbed core samples (around 24 at each site) were also randomly collected to estimate bulk density (Coile, 1936) following the same experimental design.

Soil penetration resistance (SPR) was quantified in the same sites as bulk density using an Eijkelkamp ${ }^{\otimes}$ Penetrologger device (cone: $1 \mathrm{~cm}^{2}$, $60^{\circ}$ angle; speed: $5 \mathrm{~cm} \mathrm{~s}^{-1}$ ) for 890 random points at different depths $(0-80 \mathrm{~cm})$ and soil moisture contents during 2 field campaigns: September 2010 (dry conditions) and November 2010 (wet conditions) in all 22 units. Dry conditions were considered to be when soil moisture content at sampling time was below $20 \%$ and wet conditions above $20 \%$ according to values shown by Lozano-Parra et al. (2015). The values were the means of measurements taken at $1 \mathrm{~cm}$ intervals.

\subsection{Data analysis}

Since the fundamental relationships between animal stocking rates and soil compaction, particularly bulk density, have been reported in

Table 1

Characteristics of the study areas. ASR: animal stocking rate, AU: animal unit, TD: tree density.

\begin{tabular}{|c|c|c|c|c|c|c|c|}
\hline Farm & Unit & Surface (ha) & Rainfall (mm) & Soil type & Livestock & $\operatorname{ASR}\left(\mathrm{AU} \mathrm{ha}{ }^{-1}\right)$ & TD (trees ha ${ }^{-1}$ ) \\
\hline 1 & 1 & 46.2 & 731.8 & Cambisol & Cattle, pigs & 0.54 & 17.0 \\
\hline 1 & 2 & 103.5 & 731.8 & Leptosol & Cattle, pigs & 0.54 & 24.6 \\
\hline 2 & 3 & 37.6 & 504.8 & Leptosol & Sheep & 0.62 & 0.0 \\
\hline 2 & 4 & 136.5 & 504.8 & Leptosol & Sheep & 0.19 & 0.0 \\
\hline 3 & 5 & 33.2 & 591.8 & Cambisol & Cattle, pigs, sheep & 1.82 & 21.8 \\
\hline 3 & 6 & 2.8 & 591.8 & Leptosol & Cattle, pigs, sheep & 15.76 & 0.0 \\
\hline 4 & 7 & 146.2 & 596.2 & Luvisol & Sheep, pigs & 1.09 & 34.8 \\
\hline 4 & 8 & 30.3 & 596.2 & Luvisol & Sheep, pigs & 1.19 & 12.2 \\
\hline 4 & 9 & 74.1 & 596.2 & Leptosol & Sheep, pigs & 1.09 & 29.3 \\
\hline 4 & 10 & 19.1 & 596.2 & Luvisol & Sheep, pigs & 2.99 & 71.3 \\
\hline 5 & 11 & 21.8 & 646.3 & Leptosol & Sheep, goats & 1.17 & 42.6 \\
\hline 5 & 12 & 52.0 & 646.3 & Leptosol & Sheep, goats & 1.17 & 34.3 \\
\hline 6 & 13 & 10.7 & 661.1 & Cambisol & Sheep & 0.59 & 2.4 \\
\hline 6 & 14 & 12.8 & 661.1 & Leptosol & Cattle & 0.78 & 7.3 \\
\hline 7 & 15 & 120.3 & 526.9 & Cambisol & Sheep & 0.25 & 0.0 \\
\hline 7 & 16 & 120.3 & 526.9 & Leptosol & Sheep & 0.25 & 0.0 \\
\hline 8 & 17 & 34.2 & 565.2 & Cambisol & Sheep, pigs & 0.54 & 81.1 \\
\hline 8 & 18 & 24.1 & 565.2 & Cambisol & Sheep, pigs & 0.54 & 66.4 \\
\hline 9 & 19 & 24.5 & 689.3 & Cambisol & Cattle, pigs & 0.59 & 99.9 \\
\hline 9 & 20 & 6.2 & 689.3 & Cambisol & Cattle, pigs & 0.59 & 148.1 \\
\hline 10 & 21 & 7.1 & 681.3 & Leptosol & Sheep, pigs & 0.43 & 49.8 \\
\hline 10 & 22 & 19.7 & 681.3 & Cambisol & Sheep, pigs & 0.43 & 107.4 \\
\hline
\end{tabular}


previous research (Pulido et al., 2016), this study focused on i) the description and analysis of bulk density and soil penetration resistance in the 22 studied areas, and ii) exploring the relationships between bulk density, penetration resistance and the classes of frequency of herbaceous roots observed. These classes were quantified by assigning values of $0,1,2$, and 3 to the qualitative classes none, few, common and many, respectively. Therefore, all variables were pair-wise correlated and their mean values compared between the different classes of root frequency. As the penetrometer returned values of penetration resistance using the centimetre scale, i.e. from the soil surface $(0 \mathrm{~cm})$ to $80 \mathrm{~cm}$ depth, all variables in this study (animal stocking rates and many soil properties) were also fitted to return values at centimetre scale. Statiscal analyses were carried out using the Statistica ${ }^{\circledR} 6.0$ software package (Statsoft, 2001).

\section{Results}

We considered 18 variables in this study. Three of them were considered to be factors (rainfall, animal stocking rate and tree density) and the remaining ones were considered to be study variables (organic matter, bulk density, dry and wet penetration resistance and frequency of roots). The latter were differentiated according to pre-established depth intervals: $0-5,5-10$ and $>10 \mathrm{~cm}$, therefore totalling 15 (5 variables $\times 3$ depth intervals).

Table 2 shows the coefficients of pair-wised correlation (Pearson's) between mean values by unit $(N=22)$ for these 18 variables. Animal stocking rate was significantly correlated $(r=-0.43, p<0.05)$ with the frequency of herbaceous roots at the $5-10 \mathrm{~cm}$ depth interval. Tree density was positively correlated with the frequency of roots at three depth intervals and negatively with bulk density.

\subsection{Soil compaction}

Soil compaction was analysed through the bulk density and penetration resistance values at different depths and by comparing units (or groups of units) under different grazing intensities. Table 3 shows the mean values of bulk density and penetration resistance in dry and wet conditions by unit at different depth intervals as well as the content of soil organic matter and the dominant texture. Bulk densities ranged from 1.29 to $1.63 \mathrm{~g} \mathrm{~cm}^{-3}$, from 1.33 to $1.67 \mathrm{~g} \mathrm{~cm}^{-3}$ and from 1.40 to $1.75 \mathrm{~g} \mathrm{~cm}^{-3}$ at the $0-5 \mathrm{~cm}, 5-10 \mathrm{~cm}$ and $>10 \mathrm{~cm}$ depth intervals, respectively, showing a logical increasing trend with depth. The highest values of bulk density were found in the units with lower organic matter contents.

According to the $t$-test for independent samples, SPR values were comparatively higher under dry conditions than wet, particularly for the 5 to $10 \mathrm{~cm}$ and $>10 \mathrm{~cm}$ depths. At the soil surface $(0-5 \mathrm{~cm}$ depth interval), SPR ranged from 1.30 to $2.60 \mathrm{MPa}$ under dry conditions and from 1.33 to $2.52 \mathrm{MPa}$ under wet conditions, showing differences between them that were below $0.90 \mathrm{MPa}$ in all cases. Penetration resistance increased progressively with depth under dry conditions (mean of all units: $2.06 \mathrm{MPa}(0-5 \mathrm{~cm}), 3.19 \mathrm{MPa}(5-10 \mathrm{~cm})$ and $4.37 \mathrm{MPa}$ $(>10 \mathrm{~cm})$ ) as well as under wet conditions (mean of all units: 2.10 MPa (0-5 cm), 2.89 MPa (5-10 cm) and 3.36 MPa (> $10 \mathrm{~cm})$ ).

Fig. 2 shows the scatterplot of bulk density estimates from deeper than $10 \mathrm{~cm}$ (in the units where it was possible) against the soil organic matter contents from the $0-5 \mathrm{~cm}$ and $5-10 \mathrm{~cm}$ depths. Results revealed a negative relationship with less variability from the 5 to $10 \mathrm{~cm}$ depth.

The impact of grazing intensity on SPR with depth showed that the lowest ASR had the lowest SPR values contrasting to the SPR values that were found in the highest ASR (Fig. 3). The lowest ASR corresponded to Unit 4, which had the lowest values of ASR of all the study areas (0.19 AU ha $\left.{ }^{-1}\right)$. Traditional grazing groups were all the units that had ASR below $1 \mathrm{AU} \mathrm{ha}{ }^{-1}$, and heavy grazing were those with ASRs above $1 \mathrm{AU} \mathrm{ha}^{-1}$. Finally, the highest ASR represented the most extreme case (Unit 6) of grazing intensity with a rate of $15.76 \mathrm{AU} \mathrm{ha}^{-1}$. The

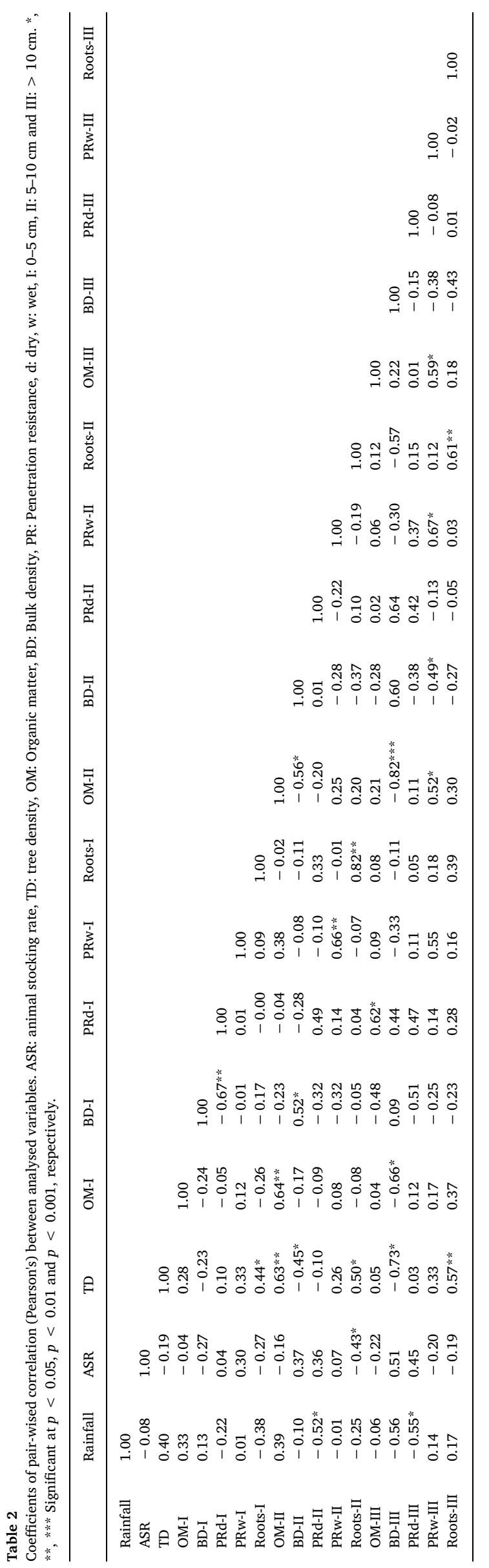


Table 3

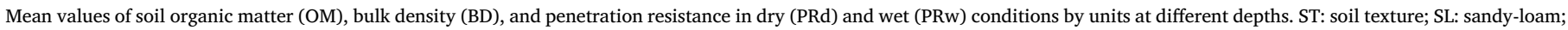
Lo: loam; SiL: silty-loam.

\begin{tabular}{|c|c|c|c|c|c|c|c|c|c|c|c|c|c|c|c|}
\hline & \multicolumn{5}{|c|}{$0-5 \mathrm{~cm}$} & \multicolumn{5}{|c|}{$5-10 \mathrm{~cm}$} & \multicolumn{5}{|c|}{$>10 \mathrm{~cm}$} \\
\hline & ST & OM (\%) & $\mathrm{BD}\left(\mathrm{g} \mathrm{cm}^{-3}\right)$ & PRd (MPa) & PRw (MPa) & ST & OM (\%) & $\mathrm{BD}\left(\mathrm{g} \mathrm{cm}^{-3}\right)$ & PRd (MPa) & PRw (MPa) & ST & OM (\%) & $\mathrm{BD}\left(\mathrm{g} \mathrm{cm}^{-3}\right)$ & PRd (MPa) & PRw (MPa) \\
\hline 1 & SL & 5.17 & 1.58 & 1.63 & 1.36 & Lo & 1.92 & 1.63 & - & 0.69 & SiL & 0.96 & 1.60 & 2.59 & - \\
\hline 2 & SL & 4.31 & 1.46 & 1.87 & 1.86 & SL & 2.05 & 1.48 & 1.00 & - & - & - & - & - & - \\
\hline 3 & SL & 4.97 & 1.33 & 2.12 & 1.48 & SL & 1.34 & 1.55 & 3.85 & 2.40 & SL & 1.03 & - & 4.84 & 2.93 \\
\hline 4 & SL & 1.33 & 1.55 & 2.03 & 1.33 & SL & 0.90 & 1.48 & 3.34 & 1.52 & Lo & 0.70 & - & 4.42 & 2.61 \\
\hline 5 & SL & 5.25 & 1.36 & 2.46 & 2.30 & Lo & 2.15 & 1.47 & 4.45 & 3.31 & SiL & 0.83 & - & 5.60 & 3.56 \\
\hline 6 & Lo & 3.61 & 1.34 & 2.00 & 2.50 & - & - & - & - & 2.96 & - & - & - & - & 3.12 \\
\hline 7 & SL & 2.50 & 1.56 & 1.86 & 2.16 & Lo & 0.94 & 1.67 & 3.18 & 2.90 & Lo & 0.00 & 1.62 & 4.27 & 2.56 \\
\hline 8 & SL & 2.59 & 1.46 & 2.28 & - & Lo & 1.31 & 1.65 & 3.32 & - & Lo & 1.50 & 1.75 & 4.15 & 2.80 \\
\hline 9 & SL & 6.01 & 1.32 & 2.36 & - & $\mathrm{SiL}$ & 1.84 & 1.52 & 2.63 & - & SiL & 1.39 & 1.56 & 5.16 & 3.49 \\
\hline 10 & SL & 3.87 & 1.46 & - & 2.03 & SL & 1.47 & 1.64 & - & 2.55 & Lo & 0.43 & 1.69 & - & 2.41 \\
\hline 11 & SL & 2.72 & 1.35 & - & 1.89 & SL & 1.05 & 1.61 & - & 3.19 & - & - & - & - & 3.67 \\
\hline 12 & SL & 3.62 & 1.45 & - & 1.90 & SL & 0.77 & 1.53 & - & 2.82 & - & - & - & - & 3.48 \\
\hline 13 & SL & 3.46 & 1.63 & - & 2.48 & SL & 1.20 & 1.60 & - & 2.53 & - & - & - & 3.36 & - \\
\hline 14 & SL & 3.87 & 1.50 & - & 1.94 & - & - & - & - & 4.15 & - & - & - & - & - \\
\hline 15 & SL & 3.81 & 1.46 & 1.91 & - & SL & 1.69 & 1.55 & 3.62 & - & SL & 0.68 & - & - & 3.98 \\
\hline 16 & SL & 3.78 & 1.56 & 1.30 & 2.50 & SL & 1.65 & 1.58 & 2.34 & 3.30 & Lo & 0.77 & - & 3.97 & 3.80 \\
\hline 17 & SiL & 3.24 & 1.41 & 2.60 & 2.47 & $\mathrm{SiL}$ & 1.87 & 1.52 & 3.28 & 3.28 & SiL & 2.06 & 1.64 & 3.74 & 4.94 \\
\hline 18 & SL & 3.76 & 1.34 & 2.18 & - & Lo & 1.88 & 1.38 & 3.21 & - & Lo & 1.20 & 1.59 & 5.65 & 3.76 \\
\hline 19 & SL & 5.64 & 1.42 & 1.99 & 2.06 & SiL & 1.94 & 1.52 & 3.02 & 2.93 & Lo & 0.68 & 1.52 & 3.42 & 2.93 \\
\hline 20 & SL & 5.56 & 1.52 & 1.61 & 2.52 & $\mathrm{SiL}$ & 3.01 & 1.46 & 2.62 & 3.41 & SiL & 0.66 & 1.40 & 4.64 & 3.97 \\
\hline 21 & SL & 3.67 & 1.42 & 1.62 & 2.10 & SL & 1.85 & 1.47 & 2.83 & 3.03 & - & - & - & 2.69 & 3.76 \\
\hline 22 & SL & 3.52 & 1.29 & 2.38 & - & SL & 2.35 & 1.33 & 3.38 & - & SL & 1.16 & 1.53 & 4.25 & 4.01 \\
\hline
\end{tabular}

recorded values of SPR in unit 6 were much higher in the first $8 \mathrm{~cm}$ than in the other units, exceeding $2 \mathrm{MPa}$ even at the soil surface. In contrast, the lowest ASR showed the lowest values of SPR, exceeding 2 MPa only below $15 \mathrm{~cm}$ depth. No significant differences were found when comparing heavy and traditional grazing. They both exceeded the threshold of $2 \mathrm{MPa}$ at $2 \mathrm{~cm}$ depth.

\subsection{Effects of soil compaction on the frequency of herbaceous roots}

Bulk density and SPR were analysed along with the classes of the frequency of herbaceous roots observed. No significant relationship was found between bulk density and the frequency of roots. Penetration resistance (in dry and wet conditions) was a key factor determining the frequency of herbaceous roots. An inverse relationship between SPR and the frequency of roots was observed.

Fig. 4 shows the mean values of SPR (in dry and wet conditions) by classes of frequency of roots. Above $2.5 \mathrm{MPa}$ a decrease from many to common was observed and above $4 \mathrm{MPa}$ the frequency of observed roots is practically none. According to the Fisher-LSD test, 3 significant homogeneous groups were identified. The first group was formed by soil horizons without herbaceous roots and with high penetration resistance values (4.51 MPa), the second group included most of the surface horizons and had many roots (2.15 MPa), and finally, an intermediate group that included the few and common classes.

Table 4 shows the mean values of the assigned classes of the frequency of roots by units at different depth intervals. The logical decrease in depth is also observed in all the units. Nevertheless, some interesting differences between units were found, particularly in the 5

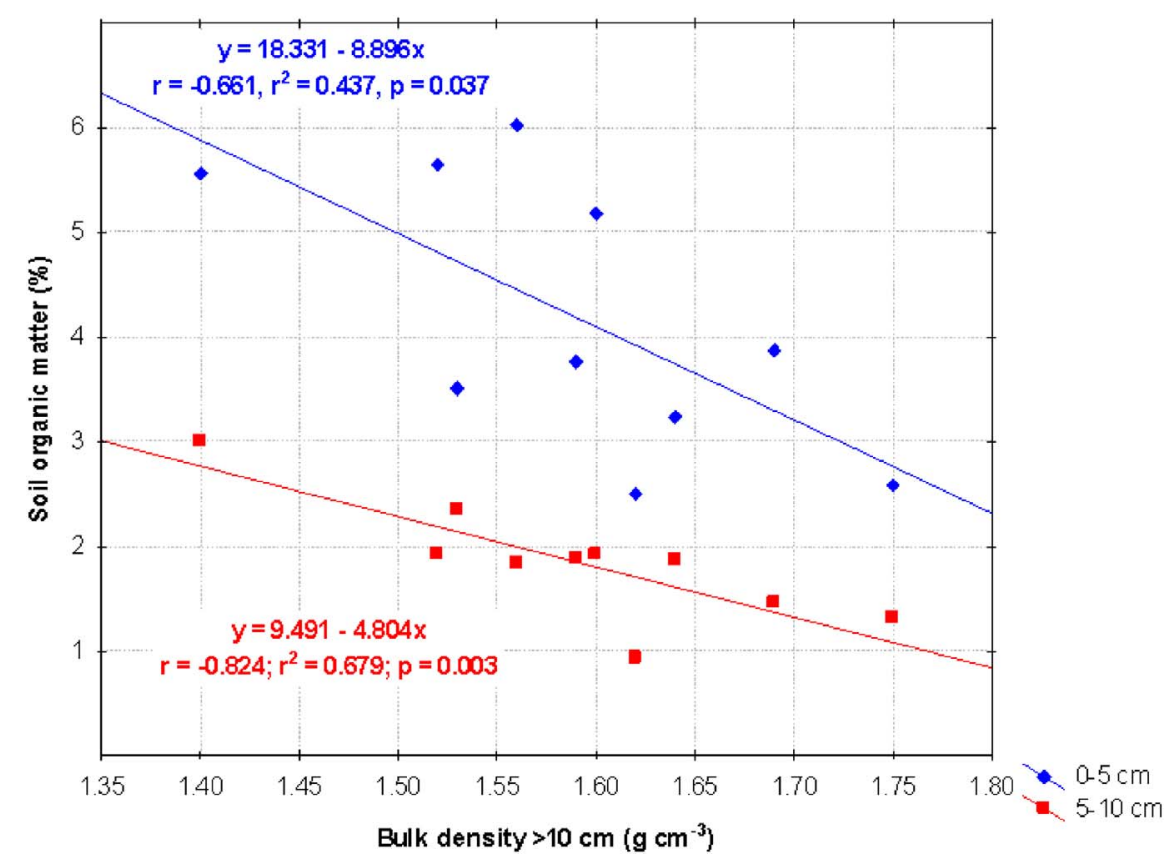

Fig. 2. Scatterplot between bulk density from $>10 \mathrm{~cm}$ and soil organic matter from the $0-5 \mathrm{~cm}$ and $5-10 \mathrm{~cm}$ depth intervals. 


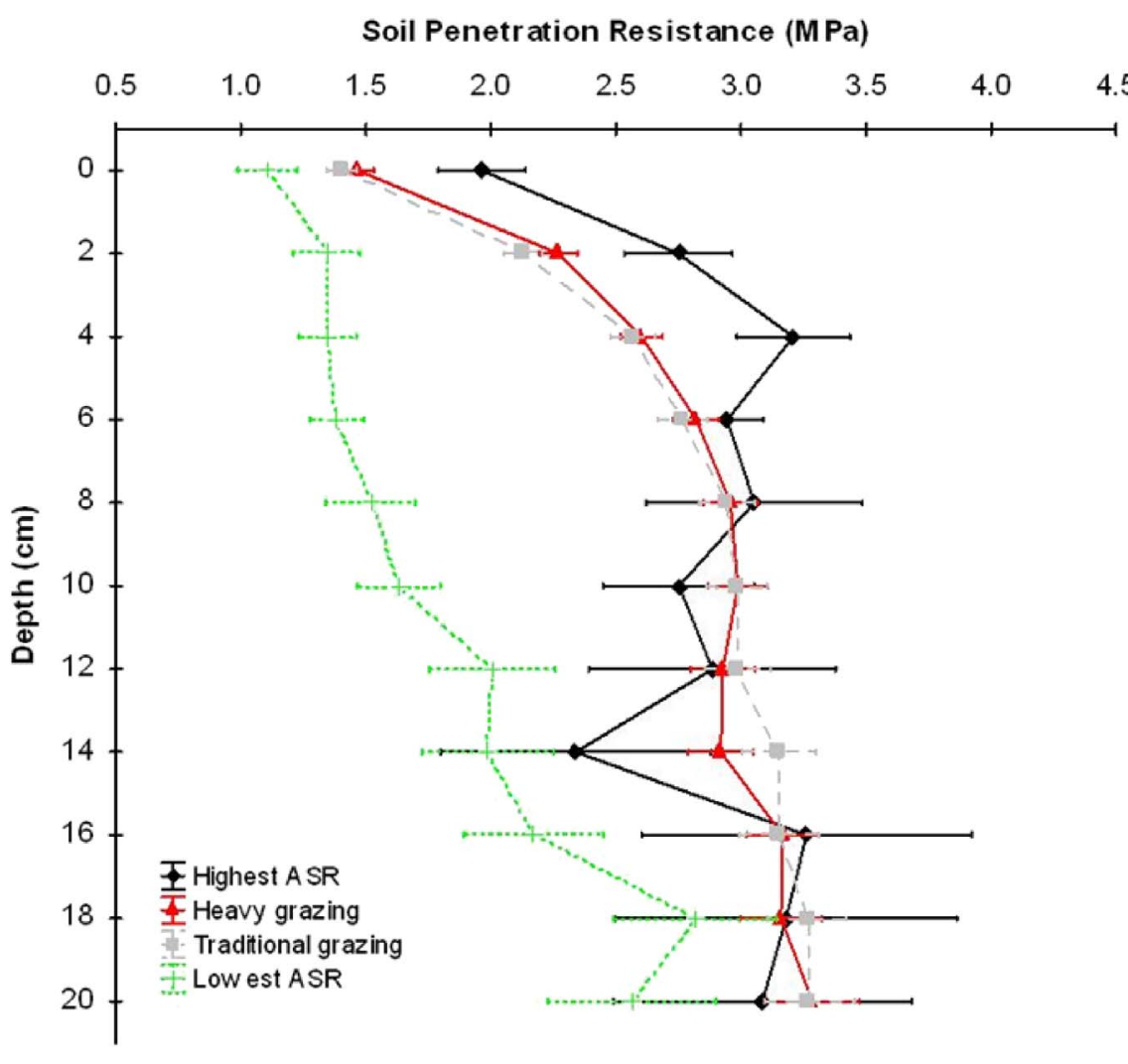

Fig. 3. Variation of soil penetration resistance with depth $(0-20 \mathrm{~cm})$ based on grazing intensity. Points and whiskers represent mean values \pm 1 standar error.

to $10 \mathrm{~cm}$ depth interval. A higher quantity of herbaceous roots (in all depth intervals) was found in the units with higher tree density. Units with relatively high ASRs showed a low frequency of herbaceous roots from the 5 to $10 \mathrm{~cm}$ depth interval.

\section{Discussion}

Livestock management is crucial both to guarantee food security in some parts of the world and to provide vital ecosystem services in Mediterranean rangelands (Papanastasis et al., 2017). Furthermore, grazing has also been demonstrated to be a helpful tool to promote the sustainable development of marginal and/or protected areas (Bernués et al., 2005), increase biodiversity (Barbaro et al., 2001) and reduce wildfire risk (Davies et al., 2010).

Grazing can be considered an important factor of alteration in human-induced natural environments such as rangelands due mainly to animal treading and biomass consumption. Animal treading generally reduces soil porosity and infiltration while increasing bulk density (Drewry et al., 2008). Nevertheless, recent studies in rangelands of SW Spain suggest mismanagement in the form of excessive numbers of animals could be the cause of soil compaction in recent decades.

Pulido et al. (2016) found high values of bulk density in the 5 to $10 \mathrm{~cm}$ depth interval in heavily grazed areas (ASR $>1 \mathrm{AU} \mathrm{ha}^{-1}$ ). These results are logically (conducted in the same study areas) in consonance with the significant coefficient of correlation $(r=-0.43$, $p<0.05$ ) observed between ASR and the frequency of roots in the $5-10 \mathrm{~cm}$ depth interval in this work (Table 2). Mean values of bulk density by units recorded in Table 3 are within the limits that restrict root growth and plant yield (1.3-1.7 $\mathrm{g} \mathrm{cm}^{-3}$ ) reported by Houlbrooke et al. (1997) for ryegrass fields in New Zealand.

As expected, bulk density increased with depth (Table 3) as deeper horizons are denser than the most surficial layers of the profile because they support the overlying material and typically have lower organic carbon content (Hanna and Al-Kaisi, 2002). An interesting relationship between the soil organic matter content at the $0-5 \mathrm{~cm}$ and $5-10 \mathrm{~cm}$ depth intervals and bulk density estimated below $10 \mathrm{~cm}$ depth was found (Fig. 2). These results reinforce the necessity of further research on physical properties in the deeper soil layers as was argued by Drewry et al. (2008).

These findings also provide evidence about the influence of underlying processes on soil surface properties. It suggests a possible limitation in the capacity of some vegetation species such as holm oak to scavenge soil nutrients and recycle them via litterfall (Moreno and Obrador, 2007). However, no evidence supporting a link between increased bulk density above the $10 \mathrm{~cm}$ depth and higher ASR was found.

Penetration resistance is strongly affected by soil moisture content (Vaz et al., 2011). The large spatial variability of soil moisture forced us to reject some measurements and to gather the accepted ones into two groups (dry and wet). Penetration resistance was higher under dry conditions (Tables 3 and 4). Notwithstanding, the values recorded from the $0-5 \mathrm{~cm}$ depth interval did not show significant differences between the two moisture states.

Similar to bulk density, SPR values showed an increase with depth. Nevertheless, high values of SPR were recorded even at the soil surface (depth: $=0 \mathrm{~cm}$ ). Approximately $20 \%$ of the valid measurements recorded had values of $>2 \mathrm{MPa}$ at the $0 \mathrm{~cm}$ depth and $70 \%$ exceeded this value at the $5 \mathrm{~cm}$ depth, meaning the vegetation had overcome the root growth-restricting limit proposed by Greacen (1986). These values could be interpreted as indications of problems related to surficial compaction being in agreement with the research of Blanco-Sepúlveda (2009), carried out in mountainous rangelands grazed by goats.

The bulk density increase will induce a loss in soil quality and as a consequence a loss of services the soils offer to humankind (Mol and Keesstra, 2012). This is why it is important to implement strategies to reduce the soil bulk density, encourage the growth of plants (roots), and avoid the loss of organic matter (Parras-Alcántara et al., 2016; Khaledian et al., 2017). This has been found in agriculture land where soil erosion rates are high under temperate and Mediterranean climatic conditions (Comino et al., 2016). The use of organic matter and recovery of vegetation important strategies to recover soil functions 

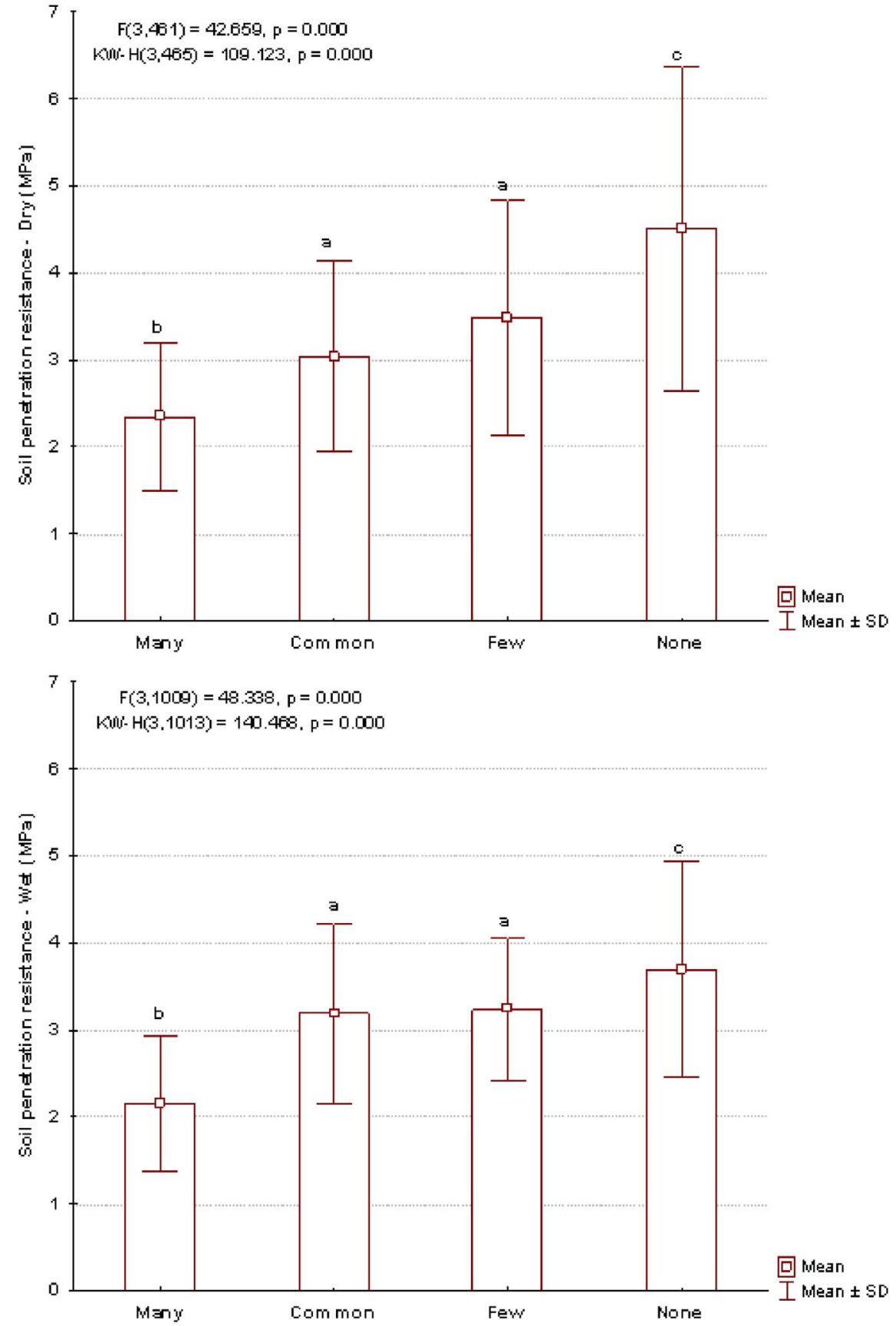

Fig. 4. Comparison of mean values ( \pm SD) of soil penetration resistance under dry and wet conditions by classes of frequency of herbaceous roots. Sample size (number of observations) of each category was many: 20, common: 19 , few: 9 , and none: 35 . Lowercase letters indicate homogenous groups (Fisher-LSD, $p<0.05$ ).
(Kirchhoff et al., 2017) and reduce soil losses as the connectivity of flow is reduced due to increased soil infiltration rates (Masselink et al., 2017). This is linked to management sustainability as promoted by the United Nations through the UN Goals for sustainability (Keesstra et al., 2016).

The root-growth restricting limits of SPR between the $2 \mathrm{MPa}$ proposed by Greacen (1986) and 3 MPa suggested by Sojka et al. (2001) are clearly exceeded at different depths of the soil profiles analysed here. Nonetheless, a relatively high abundance of herbaceous roots was observed in some soil horizons in which SPR had exceeded these abovementioned thresholds, although they are below limits of $5 \mathrm{MPa}$ and $8 \mathrm{MPa}$ reported by Glinski and Lipiec (1990) for oats and ryegrass fields, respectively. These findings could open a new discussion about the adaptation of some herbaceous species to soil compaction in this land system or a hypothetical selection of natural species to restore these areas since livestock were introduced many centuries ago.
Bulk density and SPR values were not strongly related to one another. Therefore, we should be careful interpreting one of these variables using the other as they are not comparable in many cases. Soil compaction occurs easily when soil is saturated (Bilotta et al., 2007) but it is under dry conditions that the highest values of SPR are recorded. Further research to propose a root-growth limit to grasses in Mediterranean rangelands and to investigate the effects of deeper horizons on the contents of nutrients and organic matter in the whole soil profile should be priority goals for future research on soil quality in grazing areas.

\section{Conclusion}

The frequency of herbaceous roots decreased as soil penetration resistance increased, indicating a possible threshold of $3 \mathrm{MPa}$ beyond which the abundance of grass roots decreased notably. It was not 
Table 4

Mean values of classes of frequency of roots, and penetration resistance under dry (PRd) and wet (PRw) conditions by units at different depth intervals.

\begin{tabular}{|c|c|c|c|c|c|c|c|c|c|}
\hline \multirow[b]{2}{*}{ Unit } & \multicolumn{3}{|l|}{$0-5 \mathrm{~cm}$} & \multicolumn{3}{|l|}{$5-10 \mathrm{~cm}$} & \multicolumn{3}{|l|}{$>10 \mathrm{~cm}$} \\
\hline & Roots (classes) & PRd (MPa) & PRw (MPa) & Roots (classes) & PRd (MPa) & PRw (MPa) & Roots (classes) & PRd (MPa) & PRw (MPa) \\
\hline 1 & 2.00 & 1.63 & 1.36 & 1.00 & - & 0.69 & 0.01 & 2.59 & - \\
\hline 2 & 1.50 & 1.87 & 1.86 & 0.40 & 1.00 & - & 0.00 & - & - \\
\hline 3 & 2.67 & 2.12 & 1.48 & 2.00 & 3.85 & 2.40 & 0.09 & 4.84 & 2.93 \\
\hline 4 & 3.00 & 2.03 & 1.33 & 3.00 & 3.34 & 1.52 & 0.17 & 4.42 & 2.61 \\
\hline 5 & 2.00 & 2.46 & 2.30 & 0.00 & 4.45 & 3.31 & 0.00 & 5.60 & 3.56 \\
\hline 6 & 2.00 & 2.00 & 2.50 & 0.00 & - & 2.96 & 0.00 & - & 3.12 \\
\hline 7 & 2.83 & 1.86 & 2.16 & 2.00 & 3.18 & 2.90 & 0.11 & 4.27 & 2.56 \\
\hline 8 & 3.00 & 2.28 & - & 2.20 & 3.32 & - & 0.23 & 4.15 & 2.80 \\
\hline 9 & 2.50 & 2.36 & - & 2.00 & 2.63 & - & 0.66 & 5.16 & 3.49 \\
\hline 10 & 2.67 & - & 2.03 & 1.00 & - & 2.55 & 0.19 & - & 2.41 \\
\hline 11 & 3.00 & - & 1.89 & 1.00 & - & 3.19 & 0.04 & - & 3.67 \\
\hline 12 & 2.33 & - & 1.90 & 1.00 & - & 2.82 & 0.01 & - & 3.48 \\
\hline 13 & 2.00 & - & 2.48 & 1.00 & - & 2.53 & 0.29 & 3.36 & - \\
\hline 14 & 1.50 & - & 1.94 & 0.00 & - & 4.15 & 0.00 & - & - \\
\hline 15 & 2.83 & 1.91 & - & 2.00 & 3.62 & - & 0.00 & - & 3.98 \\
\hline 16 & 3.00 & 1.30 & 2.50 & 2.00 & 2.34 & 3.30 & 0.00 & 3.97 & 3.80 \\
\hline 17 & 3.00 & 2.60 & 2.47 & 2.20 & 3.28 & 3.28 & 0.26 & 3.74 & 4.94 \\
\hline 18 & 3.00 & 2.18 & - & 3.00 & 3.21 & - & 0.33 & 5.65 & 3.76 \\
\hline 19 & 3.00 & 1.99 & 2.06 & 3.00 & 3.02 & 2.93 & 0.94 & 3.42 & 2.93 \\
\hline 20 & 3.00 & 1.61 & 2.52 & 3.00 & 2.62 & 3.41 & 0.34 & 4.64 & 3.97 \\
\hline 21 & 3.00 & 1.62 & 2.10 & 1.50 & 2.83 & 3.03 & 0.19 & 2.69 & 3.76 \\
\hline 22 & 3.00 & 2.38 & - & 3.00 & 3.38 & - & 0.40 & 4.25 & 4.01 \\
\hline
\end{tabular}

possible to draw direct cause-effect relationships between animal stocking rates and penetration resistance or the frequency of herbaceous roots, but the consequences of high bulk densities, even in deeper horizons, on soil organic matter content was observed. Soil penetration resistance only increased in the most extreme cases and the effects of its increasing were only remarkable in the first $8 \mathrm{~cm}$. All these findings are in agreement with previous research that provided information about processes influenced by soil compaction that lead to reduced pasture production. Further research to better understand how heavy grazing affects grass production and its intermediate processes could be very useful for farm owners.

Supplementary data to this article can be found online at http://dx. doi.org/10.1016/j.catena.2017.07.019.

\section{Acknowledgements}

This work was possible thanks to funding by the Government of Extremadura (IB16052) and the European Regional Development Fund - ERDF (Reference GR15032 - GIGA Research Group). Financial support was also offered by Spanish National Research Funds projects CGL2008-01215/BTE and CGL2011-23361. We wish to thank the Laboratorio Agroalimentario y de Análisis de Residuos de Cáceres (Spain) for analysing soil samples and the members of the GeoEnvironmental Research group for their help.

\section{References}

Atwell, B.J., 1993. Response of roots to mechanical impedance. Environ. Exp. Bot. 33, 27-40.

Barbaro, L., Dutoit, T., Cozic, P., 2001. A six-year experimental restoration of biodiversity by shrub-clearing and grazing in calcareous grasslands of the French Prealps. Biodivers. Conserv. 10, 119-135.

Bengough, A.G., 1991. The penetrometer in relation to mechanical resistence to root growth. In: Smith, K.A., Mullins, C.H. (Eds.), Soil Analysis. Physical Methods. Marcel Dekker, Inc., New York, USA, pp. 431-445.

Bernués, A., Riedel, J., Asensio, M., Blanco, M., Sanz, A., Revilla, R., Casasús, I., 2005. An integrated approach to studying the role of grazing livestock systems in the conservation of rangelands in a protected natural park (Sierra de Guara, Spain). Livest. Prod. Sci. 96, 75-85.

Bilotta, G.S., Brazier, R.E., Haygarth, P.M., 2007. The impacts of grazing animals on the quality of soils, vegetation, and surface waters in intensively managed grasslands. Adv. Agron. 94, 237-280.

Blanco-Sepúlveda, R., 2009. La relación entre la densidad aparente y la resistencia mecánica como indicadores de la compactación del suelo. Agrociencia 43, 231-239.
Brevik, E.C., Fenton, T.E., Moran, L.P., 2002. Effect of soil compaction on organic carbon amounts and distribution, South-Central Iowa. Environ. Pollut. 116, S137-S141.

Busscher, W.J., Sojka, R.E., 1987. Enhancement of subsoiling effect on soil strength by conservation tillage. Trans. ASAE 30, 888-892.

Coile, T.S., 1936. Soil samplers. Soil Sci. 42, 139-142.

Comino, J.R., Quiquerez, A., Follain, S., Raclot, D., Le Bissonnais, Y., Casalí, J., Giménez, R., Cerdà, A., Keesstra, S., Brevik, E., 2016. Soil erosion in sloping vineyards assessed by using botanical indicators and sediment collectors in the Ruwer-Mosel valley. Agric. Ecosyst. Environ. 233, 158-170.

Davies, K.W., Bates, J.D., Svejcar, T.J., Boyd, C.S., 2010. Effects of long-term livestock grazing on fuel characteristics in rangelands: an example from the sagebrush steppe. Rangel. Ecol. Manag. 63, 662-669.

Díaz, M., Campos, P., Pulido, F.J., 1997. The Spanish Dehesa: a diversity in land-use and wildlife. In: Pain, D.J., Pienkowski, M.W. (Eds.), Farming and Birds in Europe. Academic Press, San Diego, pp. 178-209.

Donkor, N.T., Gedir, J.V., Hudson, R.J., Bork, E.W., Chanasyk, D.S., Naeth, M.A., 2002. Impacts of grazing systems on soil compaction and pasture production in Alberta. Can. J. Soil Sci. 82, 1-8.

Drewry, J., Cameron, K., Buchan, G., 2008. Pasture yield and soil physical property responses to soil compaction from treading and grazing - a review. Aust. J. Soil Res. 46, $237-256$.

FAO, 2006. Guidelines for Soil Description, Fourth Edition. Food and Agriculture Organization of the United Nations, Rome, Italy.

Gea-Izquierdo, G., Cañellas, I., Montero, G., 2006. Acorn production in Spanish holm oak woodlands. Investigación Agraria: Sistemas y Recursos Forestales 15, 339-354.

Gerrard, A.J., 1982. The use of hand-operated soil penetrometers. Area 14, 227-234.

Glab, T., 2013. Impact of soil compaction on root development and yield of meadowgrass. International Agrophysics 27, 7-13.

Glinski, J., Lipiec, J., 1990. Soil Conditions and Plant Roots. CRC Press, Boca Raton, FL.

Gómez Amelia, D., 1985. La Penillanura Extremeña. Estudio Geomorfológico. Universidad de Extremadura, Cáceres, Spain.

González, F., Murillo, M., Paredes, J., Prieto, P.M., 2007. Recursos pascícolas de la dehesa extremeña. Primeros datos para la modelización de su gestión. Pastos 37, 231-239.

Gonzalo Langa, J., 2011. El impacto de la aplicación de la PAC en las producciones ganaderas de la Dehesa (1986-2010). In: Coleto Martínez, J.M., De Muslera Pardo, E. González Blanco, R., Pulido García, F. (Eds.), La Agricultura y la Ganadería Extremeñas: Informe 2010. Caja de Ahorros de Badajoz, Badajoz, España, pp. 181-196.

Greacen, E.L., 1986. Root response to soil mechanical properties. Transactions of the 13th Congress of the International Society of Soil Science 5, 20-47.

Greacen, E.L., Sands, R., 1980. Compaction of forest soils. A review. Aust. J. Soil Res. 18, 163-189.

Greenwood, K.L., McKenzie, B.M., 2001. Grazing effects on soil physical properties and the consequences for pastures: a review. Aust. J. Exp. Agric. 41, 1231-1250.

Gupta, S.C., Sharma, P.P., DeFranchi, S.A., 1989. Compaction effects on soil structure. In: Brady, N.C. (Ed.), Advances in Agronomy. Vol. 42. Academic Press, pp. 311-338.

Hakansson, I., Lipiec, J., 2000. A review of the usefulness of relative bulk density values in studies of soil structure and compaction. Soil Tillage Res. 53, 71-85.

Hanna, M., Al-Kaisi, M., 2002. Resources Conservation Processes: Understanding and Managing Soil Compaction. Iowa State University Extension, Ames, Iowa, USA.

Houlbrooke, D.J., Thom, E.R., Chapman, R., McLay, C.D.A., 1997. A study of the effects of soil bulk density on root and shoot growth of different ryegrass lines. N. Z. J. Agric. Res. 40, 429-435. 
Joffre, R.S., Rambal, S., Rattet, J.P., 1999. The dehesa system of southern Spain and Portugal as a natural ecosystem mimic. Agrofor. Syst. 45, 57-79.

Keesstra, S.D., Quinton, J.N., van der Putten, W.H., Bardgett, R.D., Fresco, L.O., 2016. The significance of soils and soil science towards realization of the United Nations sustainable development goals. Soil 2, 111-128.

Khaledian, Y., Kiani, F., Ebrahimi, S., Brevik, E.C., Aitkenhead-Peterson, J., 2017. Assessment and monitoring of soil degradation during land use change using multivariate analysis. Land Degrad. Dev. 28, 128-141.

King, R., Proudfoot, L., Smith, B., 2014. The Mediterranean: Environment and Society. Routledge, New York.

Kirchhoff, M., Rodrigo-Comino, J., Seeger, M., Ries, J., 2017. Soil erosion in sloping vineyards under conventional and organic land use managements (Saar-Mosel valley, Germany). Cuadernos de Investigación Geográfica 43, 119-140.

Lachica, M., Aguilera, J., 2000. Estimation of the energy costs of locomotion in the Iberian pig (Sus mediterraneus). Br. J. Nutr. 83, 35-41.

Lavado Contador, J.F., Pulido Fernández, M., Schnabel, S., Herguido Sevillano, E., 2015. Fragmentation of SW Iberian rangeland farms as assessed from fencing and changes in livestock management. Effects on soil degradation. In: Alphan, H., Atik, M. Baylan, E., Karadeniz, N. (Eds.), Proceedings of the International Congress on Landscape Ecology, 23-25 October 2014, Antalya, Turkey. PAD Publications No: 2pp. 183-192.

Lozano-García, B., Parras-Alcántara, L., Brevik, E.C., 2016. Impact of topographic aspect and vegetation (native and reforested areas) on soil organic carbon and nitrogen budgets in Mediterranean natural areas. Sci. Total Environ. 544, 963-970.

Lozano-Parra, J., Schnabel, S., Ceballos-Barbancho, A., 2015. The role of vegetation covers on soil wetting processes at rainfall event scale in scattered tree woodland of Mediterranean climate. J. Hydrol. 529, 951-961.

Marañón, T., Pugnaire, F.I., Callaway, R.M., 2009. Mediterranean-climate oak savannas: the interplay between abiotic environment and species interactions. Web Ecology 9, 30-43.

Masselink, R., Temme, A., Giménez, R., Casalí, J., Keesstra, S., 2017. Assessing hillslopechannel connectivity in an agricultural catchment using rare-earth oxide tracers and random forests models. Cuadernos de Investigación Geográfica 43, 19-39.

Mol, G., Keesstra, S., 2012. Soil science in a changing world. Curr. Opin. Environ. Sustain. 4, 473-477.

Moreno, G., Obrador, J.J., 2007. Effects of trees and understorey management on soil fertility and nutritional status of holm oaks in Spanish dehesas. Nutr. Cycl. Agroecosyst. 78, 253-264.

Moreno, G., Obrador, J.J., Cubera, E., Dupraz, C., 2005. Fine root distribution in Dehesas of Central-Western Spain. Plant Soil 277, 153-162.

Mulholland, B., Fullen, M.A., 1991. Cattle trampling and soil compaction on loamy sands. Soil Use Manag. 7, 189-193.

Ninyerola, M., Pons, X., Roure, J.M., 2005. Atlas Climático Digital de la Península Ibérica. Metodología y Aplicaciones en Bioclimatología y Geobotánica. Universidad
Autónoma de Barcelona, Spain.

Papanastasis, V.P., Bautista, S., Chouvardas, D., Mantzanas, K., Papadimitriou, M., Mayor, A.G., Koukioumi, P., Papaioannou, A., Vallejo, R.V., 2017. Comparative assessment of goods and services provided by grazing regulation and reforestation in degraded Mediterranean rangelands. Land Degrad. Dev. 28, 1178-1187.

Pardini, A., 2002. Mediterranean pastoral systems and the threat of globalization. Options Méditérr. 62, 155-168.

Parras-Alcántara, L., Lozano-García, B., Keesstra, S., Cerdà, A., Brevik, E.C., 2016. Longterm effects of soil management on ecosystem services and soil loss estimation in olive grove top soils. Sci. Total Environ. 571, 498-506.

Plieninger, T., Pulido, F.J., Schaich, H., 2004. Effects of land-use and landscape structure on holm oak recruitment and regeneration at farm level in Quercus ilex L. dehesas. J. Arid Environ. 57, 345-364.

Pulido, F., Picardo, Á., 2010. Libro verde de la Dehesa. In: Junta de Castilla y León, SECF, SEEP, AEET, SEO. Virtual book.

Pulido Fernández, M., 2014. Indicadores de Calidad del Suelo en Áreas de Pastoreo. Universidad de Extremadura, Cáceres (PhD Thesis).

Pulido, M., Schnabel, S., Lavado Contador, J.F., Lozano-Parra, J., González, F., 2016. The impact of heavy grazing on soil quality and pasture production in rangelands of SW Spain. Land Degrad. Dev. http://dx.doi.org/10.1002/ldr.2501.

Pulido-Fernández, M., Schnabel, S., Lavado-Contador, J.F., Miralles Mellado, I., Ortega Pérez, R., 2013. Soil organic matter of Iberian open woodland rangelands as influenced by vegetation cover and land management. Catena 109, 13-24.

Schnabel, S., 1997. Soil Erosion and Runoff Production in a Small Watershed Under SilvoPastoral Landuse (Dehesas) in Extremadura, Spain. Geoforma Ediciones, Logroño, Spain.

Soil Survey Laboratory Methods Manual, 2004. Soil Survey Investigations Report No. 42. Version 4.0. USDA-NCRS, Lincoln, USA.

Sojka, R.E., Busscher, W.J., Lehrsch, G.A., 2001. In situ strength, bulk density, and water content relationships of a durinodic xeric haplocalcid soil. Soil Sci. 166, 520-529.

Statsoft, 2001. STATISTICA (Data Analysis Software System), Version 6.

Taylor, H.M., Roberson, G.M., Parker Jr., J.J., 1966. Soil strength-root penetration relations to medium to coarse-textured soil materials. Soil Sci. 102, 18-22.

Vaz, C.M.P., Manieri, J.M., De Maria, I.C., Tuller, M., 2011. Modeling and correction of soil penetration resistance for varying soil water content. Geoderma 166, 92-101.

Voorhees, W.B., 1983. Relative effectiveness of tillage and natural forces alleviating wheel induced soil compaction. Soil Sci. Soc. Am. J. 47, 129-133.

Walkley, A., Black, L.A., 1934. An examination of Degtjareff method for determining soil organic matter and a proposed modification of the chromic acid titration method. Soil Sci. 37, 29-38.

Whalley, W.R., Watts, C.W., Gregory, A.S., Mooney, S.J., Clark, L.J., Whitemore, A.P., 2008. The effect of soil strength on the yield of wheat. Plant Soil 306, 237-247.

Willat, S.T., Pullar, D.M., 1984. Changes in soil physical properties under grazed pastures. Aust. J. Soil Res. 22, 343-348. 